\title{
FROM OLD TO NEW DEVELOPMENTALISM IN LATIN AMERICA
}

\author{
Luiz Carlos Bresser-Pereira
}

To be published in José Antonio Ocampo, ed. Handbook of Latin America Economics (Oxford University Press). December 19, 2009.

\begin{abstract}
The failure of the Washington Consensus and of macroeconomic policies based on high interest rates and non-competitive exchange rates to generate economic growth prompted Latin America to formulate national development strategies. New developmentalism is an alternative strategy not only to conventional orthodoxy but also to old-style Latin American national developmentalism. While national developmentalism was based on the tendency of the terms of trade to deteriorate and, adopting a microeconomic approach, proposed economic planning and industrialization, national-developmentalism assumes that industrialization has been achieved, although in different degrees by each country, and argues that, in order to assure fast growth rates and catching up, the tendency that must be neutralized is that of the exchange rate to overvaluation. Contrary to the claims of conventional economics, a capable state remains the key instrument to ensure economic development, and industrial policy continues to be necessary; but what distinguishes the new approach is principally growth with domestic savings instead of with foreign savings, a macroeconomic policy based on moderate interest rates and a competitive exchange rate instead of the high interest rates and the overvalued currencies prescribed by conventional orthodoxy.
\end{abstract}

Key words: national strategy structuralism developmentalism orthodoxy

JEL classification: $\mathrm{O} 10-011-\mathrm{O} 54$

From the 1930s or, at least, from the 1950s, Latin American countries adopted a successful national development strategy, namely, national developmentalism, based on development economics and in the Latin-American structuralist economic theory. In the late 1980s, after ten years of foreign debt crisis combined with high rates of inflation, this strategy required redefinition. It was replaced by the Washington Consensus or conventional orthodoxy - an imported strategy based on the deregulation of markets, growth with foreign savings, high interest rates and overvalued exchange rates. Ten years later, after

Luiz Carlos Bresser-Pereira is Emeritus Professor of Getulio Vargas Foundation. lcbresser@uol.com.br www.bresserpereira.org.br 
the 1994 Mexican, the 1998 Brazilian and the 2001 Argentinean financial crises, the failure of this strategy became evident, as it caused repetitive balance of payment crises and failed to improve living standards. On the other hand, I assume that middle-income developing countries are supposed to grow faster than rich countries and catch up. Financial globalization is a threat to that, but commercial globalization is as opportunity as the Asian experience shows. Since the early 2000s, Latin America countries have been once again seeking a national development strategy. In the political realm, this search has been expressed by the successive elections of center-left and nationalist political leaders. Yet the success of this search is not assured. What are the alternative theory and the economic policy to conventional orthodoxy? Which institutional reforms and which economic policies does such a strategy entail?

To respond to these questions we must make a realistic assessment of the different realities and levels of development existing in Latin America. The poorer a country is, the more unequal and poorly educated will be its people, and more difficult it will be to govern and to formulate appropriate economic policies. The challenges that all developing countries have faced in the 1950s, when this question was first asked by the pioneers of development economics, vary according to the stage of development of each country. ${ }^{1}$ Countries are, first, supposed to undertake primitive accumulation and to create a minimal capitalist class; second, they must complete their modernization or capitalist revolution, which involves industrialization and the formation of a truly national state; and third, after equipped with a modern business class, a large professional middle class, and a large wage-earning class, and with the basic institutions required for economic growth, countries must prove themselves capable of continuing to grow fast and of gradually catching up with the growth levels of rich countries. In Latin America I would say that all countries, except for Haiti and perhaps Nicaragua, have completed primitive accumulation, and that a group of countries, including at least Argentina, Brazil, Mexico, Chile, Uruguay and Costa Rica, have completed their capitalist revolutions and may be considered middle-income countries. This being so, it is not sufficient just to ask what the alternative to conventional orthodoxy is; in defining this alternative it is also necessary to distinguish middle-income countries from poor countries in the region, because they face

\footnotetext{
${ }^{1}$ I refer to economists like Albert Hirschman, Arthur Lewis, Celso Furtado, Gunnar Myrdal, Hans Singer, Michel Kalecki, Ragnar Nurse, Raul Presbisch and Paul Rosenstein-Rodan.
} 
different challenges. In this paper I will discuss new developmentalism in middle-income countries.

Considering the questions and the caveats set out above, I will adopt an historical method to compare the two competing strategies that Latin America faces today: conventional orthodoxy and new developmentalism. The paper is divided into five short sections. In the first, I discuss briefly old or national developmentalism, its relation to the Latin American structuralist school of thought, and its success in promoting economic growth between 1930 and 1980. In the second section, I discuss shortly the causes for the demise of national-developmentalism and its substitution by the Washington consensus or conventional orthodoxy. Given the failure of this alternative to promote stability and growth, in the third section I discuss the rise of a structuralist development macroeconomics and of new developmentalism. In the fourth section I compare new developmentalism with old developmentalism, and, fifth, new developmentalism with conventional orthodoxy. My concern in these two sections is to demonstrate that there is a sensible alternative to conventional orthodoxy - an alternative based on Latin-American structuralism and on the successful experience of fast growing Asian countries.

\section{National developmentalism and structuralism}

Between the 1930s and the 1970s, Latin American countries grew at an extraordinary pace. They took advantage of the weakness of the center in the 1930s in order to formulate national development strategies that, in essence, implied protection of the infant national industry (or import-substitution industrialization) and the promotion of forced savings by the state. Additionally, the state was supposed to make direct investments in infrastructure and in certain basic industries whose capital requirements and risks were large. This strategy was called "national developmentalism.” Such a name was designed to emphasize that, first, the policy's basic objective was to promote economic development, and, second, in order for this to happen, the nation - that is, businessmen, the state bureaucracy, the middle classes, and the workers united in international competition - had to define the means to reach this objective within the framework of the capitalist system, having the state as the principal instrument of collective action. The first statesman who devised national developmentalism in Latin America was Getúlio Vargas, who governed Brazil in 1930-45 and 1950-4. On the other hand, the notable Latin American economists, 
sociologists, political scientists and philosophers who formulated this strategy in the 1950s came together in the Economic Commission for Latin America and Caribbean (ECLAC) in Santiago, Chile, and in Instituto Superior de Estudos Brasileiros (ISEB) in Rio de Janeiro, Brazil. They developed a theory of underdevelopment and a nationalist view of economic development based on the critique of imperialism or of "the center-periphery relation" - a euphemism proper to public intellectuals associated with an organization of the United Nations. Latin American economists, among them Raul Prebisch, Celso Furtado, Osvaldo Sunkel, Anibal Pinto and Ignacio Rangel, drew on the classical political economy of Adam Smith and Karl Marx, the macroeconomics of John Maynard Keynes and Michael Kalecki, and the new ideas of the development economics school (of which they were part) to form the Latin American structuralist school. The central elements of structuralism were the critique of the law of comparative advantage in international trade, the dualist character of underdeveloped economies, the existence of unlimited supplies of labor, economic development as a structural change or as industrialization, the role of the state in producing forced savings and directly investing in key industries, the existence of structural inflation, the proposal of a national-developmentalist strategy based on import substitution industrialization, and, in the advanced stages, export promotion of manufactured goods (Cardenas, Ocampo and Thorp 2001). Whereas the structuralist thought was a Latin American version of development economics, national developmentalism was the respective national development strategy. As a state-led strategy, it understood that markets are effective in resource allocation provided that they are combined with economic planning and the constitution of state-owned enterprises. National-developmentalism was a strategy sponsored in one way or another by industrialists, the public bureaucracies and urban workers. It faced intellectual opposition from neoclassical or monetarist economists and political opposition from the liberal middle classes and the old oligarchy whose interests were based on the export of primary goods.

\section{Conventional orthodoxy}

Although the demise of national developmentalism and its replacement by conventional orthodoxy would happen only in the late 1980s, its origins are in the mid-1960s - after the military coups in Brazil (1964), Argentina (1967) and Uruguay (1968). The following historical factors contributed to this outcome: (a) the exhaustion of the state-led import- 
substitution strategy; (b) the 1980s’ major foreign debt crisis; (c) the intellectual dominance of the associated-dependency interpretation of Latin America since the early 1970s - an interpretation that dismissed the dualist and peripheral character of LatinAmerican societies; ${ }^{2}$ (d) the success of the US policy (beginning in the late 1960s) of training Latin American economists in doctoral programs in the United States, and (d) the neoliberal wave and, in the academic world, the rise of neoclassical economics, public choice theory, and new institutionalism - three sophisticated attempts to ground neoliberalism scientifically.

To replace developmentalism, Washington proposed a "consensus" formed from a cluster of orthodox macroeconomic policies and market-oriented institutional reforms including (not John Williamson's original 1990 document but since the early 1990s) the most debatable policy of all: financial liberalization - the extension of financial globalization to developing countries. The failure of conventional orthodoxy to promote Latin America's economic development is today widely acknowledged. It may be checked in Table 1, which shows the rates of growth of the main Latin American countries during 1950-80, 1981-2006 and 1990-2006. While between 1950 and 1980 the average annual growth rate of Latin American countries listed in the table was 3.11 per cent, after 1981 it was 0.77 per cent and after 19901.6 per cent. The low rate since 1981 was also caused by the great debt crisis of the 1980s, which reflected the mistaken policy of growth with foreign savings of the 1970s. The poor 1.6 per cent rate since 1990 - practically half of the rate achieved between 1950 and 1980 - is a consequence of the neoliberal policies or of the Washington Consensus in the region. The well-known exception is Chile, whose growth between 1990 and 2006 was substantially superior to the 1950-1980 periods. After ten years of radical neoliberal policies, the military regime adopted a competent liberal and export-led strategy that was pursued and improved by the democratic strategy since 1990. Argentina also presented a slightly better performance since 1990, but the major 2001 crisis showed how fragile was the prosperity derived from the "plan de convertibilidad".

The failure of conventional orthodoxy would not be so clearly demonstrated by these contrasting growth figures if the Asian countries that rejected the Washington Consensus and retained control over their economies, principally their control on the exchange rate, had also experienced falling growth rates since 1981 or 1990; it was just the opposite

\footnotetext{
${ }^{2}$ See on that matter Bresser-Pereira (1996 and 2009).
} 
what happened in China, India or Indonesia,. Their growth rates in the second period greatly increased. Thus, while convergence was taking place in the fast-growing Asian countries, Latin American countries lagged behind., clearly demonstrating what Ocampo and Parra (2007: 101 and 111) call the "dual divergence: between developing countries and the industrial world, on one hand, and among developing countries, on the other”.

Table 1: Growth and per capita income in selected countries - 1950-2006 (constant 2000 dollars)

\begin{tabular}{|l|c|c|c|c|}
\hline Country & $\begin{array}{c}\mathbf{1 9 5 0 - 1 9 8 0} \\
\text { Annual } \\
\text { growth rate } \\
\mathbf{( \% )}\end{array}$ & $\begin{array}{c}\mathbf{1 9 8 1 - 2 0 0 6} \\
\text { Annual } \\
\text { growth rate } \\
\mathbf{( \% )}\end{array}$ & $\begin{array}{c}\mathbf{1 9 9 0 - 2 0 0 6} \\
\text { Annual } \\
\text { growth rate } \\
\text { (\%) }\end{array}$ & $\begin{array}{l}\text { 2006 Income } \\
\text { per capita }\end{array}$ \\
\hline Argentina & 1.60 & 0.54 & 2.55 & 8733,4 \\
\hline México & 3.37 & 0.93 & 1.61 & 6951,5 \\
\hline Uruguay & 1.30 & 1.23 & 2.17 & 6770,2 \\
\hline Chile & 1.38 & 3.01 & 4.13 & 5889,1 \\
\hline Costa Rica & 3.16 & 1.56 & 2.75 & 4819,8 \\
\hline Panama & 3.24 & 1.55 & 3.03 & 4743,6 \\
\hline Brazil & 4.12 & 0.53 & 1.18 & 4043,1 \\
\hline Venezuela & 2.20 & -0.01 & 0.74 & 5429,6 \\
\hline Colombia & 2.28 & 1.50 & 1.64 & 2673,9 \\
\hline Peru & 2.08 & 0.36 & 2.77 & 2555,8 \\
\hline Ecuador & 3.16 & 0.63 & 1.35 & 1608,0 \\
\hline Paraguay & 2.67 & 0.07 & -0.01 & 1397,9 \\
\hline Bolivia & 0.92 & 0.00 & 1.27 & 1064,4 \\
\hline Cuba & ----- & 1.22 & 0.98 & 3890,4 \\
\hline Average & $\mathbf{3 . 1 1}$ & $\mathbf{0 . 7 7}$ & $\mathbf{1 . 6 0}$ & ---- \\
\hline
\end{tabular}

Source: www.eclac.org. Observation: average annual growth rate weighted by population. (1) Per capita income (constant 2000 dollars)

Conventional orthodoxy may be summarily defined by four propositions:(1) middleincome countries' major problem is the lack of microeconomic reforms capable of enabling the market to operate freely; (2) controlling inflation is the main purpose of macroeconomic policy, even if inflation rates are moderate; (3) in order to achieve such control, interest rates must inevitably be high, and the exchange rate correspondingly appreciated; (4) economic development is a competition among countries to obtain foreign savings (current account deficits), and, so, the foreign exchange appreciation caused by capital inflows required to finance the deficits is no cause for concern because the returns 
on the increased investment rate pay for it. ${ }^{3}$

\section{New developmentalism and development macroeconomics}

When it became manifest that the Washington Consensus was not causing growth but rather financial instability and increasing inequality, the reaction that took hold in Latin America was not surprising. It began at the political level with the election of a succession of nationalist and left-wing leaders, creating room for national policies. Yet, because most of these countries are poor, they are very difficult to govern. Their new administrations are searching for an alternative economic strategy, but the probability of success is low. At the knowledge level, however, principally in the more developed countries of the region, economists and other social scientists are seeing the success of the fast-growing Asian countries and are persuaded that, despite cultural and economic differences, such experiences may be helpful to the devising of a Latin American development alternative. The name that I have been giving to this proposed alternative strategy is "new developmentalism”.

New developmentalism is a set of values, ideas, institutions, and economic policies through which, in the early 21st century, middle-income countries seek to catch up with developed countries. It is not an economic theory but a strategy; it is a national development strategy, based mainly on Keynesian macroeconomics and structuralist development macroeconomics.\# It is the set of ideas that enables developing nations to reject rich nations' proposals and pressures for reform and economic policy, like capital account liberalization and growth with foreign savings. It is the means by which businessmen, government officials, workers and intellectuals can stand together as a true nation to promote economic development. New developmentalism is suitable for middleincome countries rather than for poor countries, not because poor countries do not require a national development strategy, but because their strategies involve accomplishing primitive accumulation and industrial revolution, or, in other words, because the challenges they face are different from those faced by middle-income countries.

The basic propositions behind new developmentalism are macroeconomic; they derive

\footnotetext{
${ }^{3}$ See Frenkel (2003), Bresser-Pereira and Nakano (2003), Bresser-Pereira and Gala (2007), Bresser-Pereira (2010).
} 
from a structuralist development macroeconomics that is being defined by critical LatinAmerican economists having as parameter the Asian experience. ${ }^{4}$ The supply aspects of economic growth including industrial policy are naturally considered in this approach, but, given its Keynesian and Kaleckian foundation, two tendencies that press down demand the tendency of wages to increase below the productivity rate and the tendency to the overvaluation of the exchange rate - are crucial to the new ideas. The first derives from the definition of a developing country as a dual economy and from the classic work of Arthur Lewis (1954) showing that developing countries face an unlimited supply of labor - and represents a major impediment to the creation of mass consumption economies in the region in the line that principally Ricardo Bielschowsky (2008) has been discussing. ${ }^{5}$ This fact implies a rise in wages when the worker migrates from the traditional sector to the modern sector, but thereafter it presses down wages in the modern sector - which causes increasing inequality and a chronic insufficiency of demand. In the 1970s, in Latin America, this problem was classically "solved" by the production of luxury goods to be consumed by the middle class and the rich, or by exporting wage goods and importing luxury goods and capital goods. ${ }^{6}$

The second structural tendency - the tendency to the overvaluation of the exchange rate explains why the exchange rate is not eventually controlled by the market, but by balance of payment crises instead. As conventional economics presupposes that wages are well equilibrated by the labor market, it supposes that the same happens with the exchange rate. Yet, if the exchange rate is left fully free in a developing country, a series of structural and policy factors will lead it to appreciate, the country will incur in current account deficit, will get indebted, will suffer from chronic financial fragility, and, finally, when foreign creditors lose confidence, will face a "sudden stop” - a balance of payment or currency crisis and a sharp devaluation.

\footnotetext{
${ }^{4}$ My own contribution to a structuralist development macroeconomics - the one that I am in some way resuming in this paper - is in Bresser-Pereira (2010) Globalization and Competition; an earlier attempt was Estado e Subdesenvolvimento Industrializado (1977). Lance Taylor (1983, 1991 ) is for long developing a structural macroeconomics. In the same line we have major contributions of Jaime Ross (2003), Roberto Frenkel (2003, 2008), and Ricardo Ffrench-Davis (2003).

${ }^{5}$ Ricardo Bielschowsky is discussing this theme since 2003 when he coordinated with Guido Mantega the Lula administration's Plano Plurianual 2004-2007, where there is a section on the long term growth strategy in which mass consumption is underlined. This was always an assumption for the work of Celso Furtado and of Antonio Barros de Castro.

${ }^{6}$ On this see Bresser-Pereira (1970, 1972, 1977) Tavares and Serra (1971), Bacha (1973 [1976]).
} 
This tendency derives from two structural factors: from the "Dutch disease" originated in Ricardian rents that drives down (appreciates) the exchange rate from the "industrial equilibrium" to the "current account equilibrium", and from the higher profit and interest rates prevailing in developing countries, which attract foreign capitals, appreciate the exchange rate below the current account equilibrium and cause current account deficits. This second structural factor, however, would not be sufficient to cause balance-ofpayments crises and, so, to justify the existence of a tendency to the overvaluation of the exchange rate if it were not amplified by economic policies inspired by conventional orthodoxy that further appreciate the national currency: (1) by the policy of growth with foreign savings, (2) by the use of inflation targeting to justify high interest rates, (3) by the use of the exchange rate as a nominal anchor to fight inflation and increase artificially wages, (4) by the policy of capital deepening aiming to increase the interest rate to attract foreign capitals. It is also amplified by (5) “exchange rate populism” - the populist practice originally discussed by Adolfo Canitrot (1976) of appreciating the currency to control inflation, increase real wages, and, in this way, getting the politician reelected.

\section{Graph 1: Tendency to the overvaluation of the exchange rate}

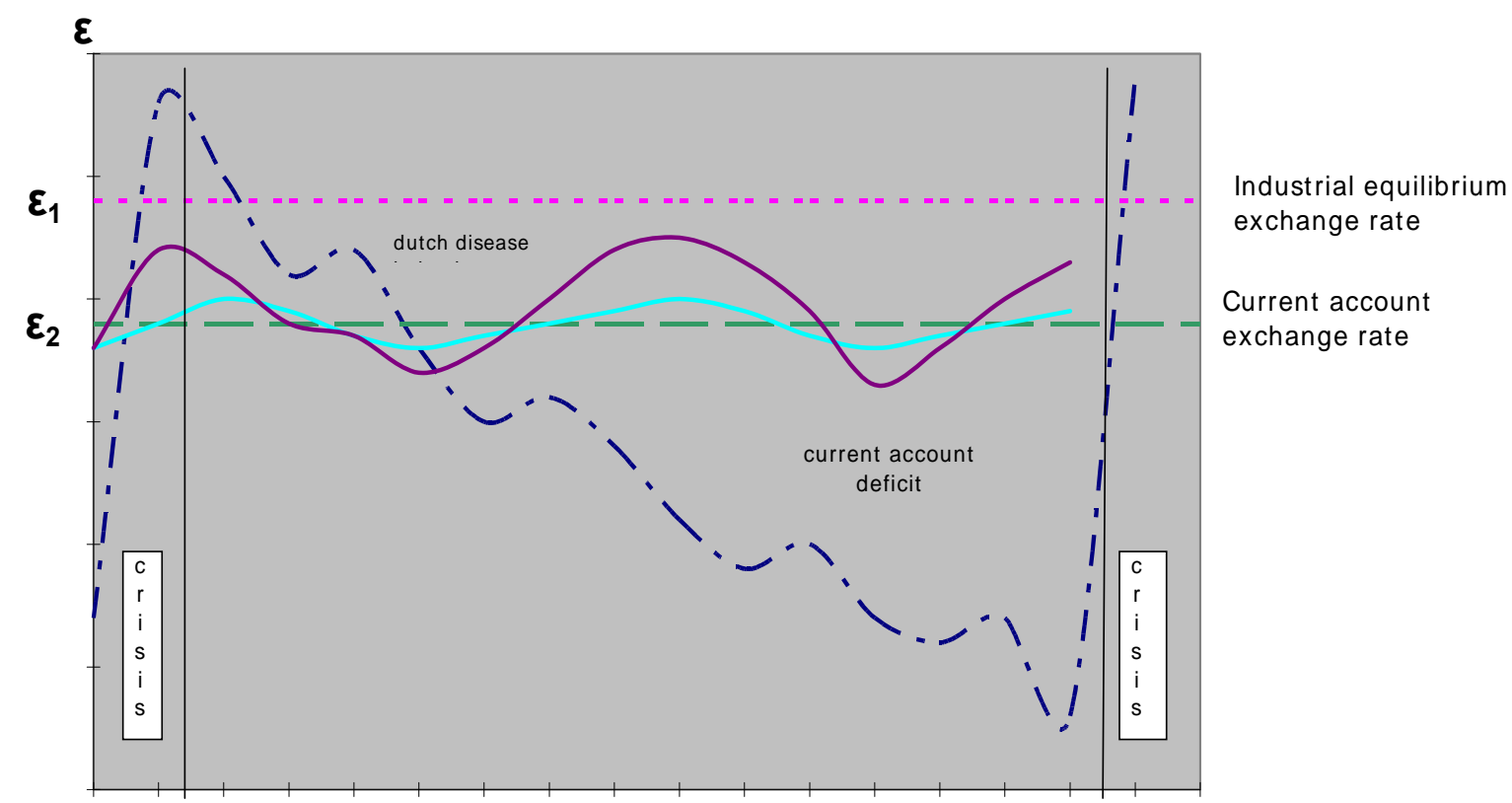

tendency to overvaluation $=-$ - ind equil ER - - CC equil ER $\longrightarrow$ orthodox $\longrightarrow$ keynesian

Given these two tendencies, new developmentalism asserts the importance of an income policy that keeps wages growing with productivity and an exchange rate policy that 
neutralizes the overvaluation tendency. Both create investment opportunities that increase the investment rate, and, in consequence, the savings rate. ${ }^{7}$ When this structuralist approach criticizes the policy of growth with foreign savings because it causes the substitution of foreign for domestic savings rather than the increase of investments, this critique is not only of conventional economics but also of development economics because the later defined the two-gap model and presented as solution foreign indebtedness. A competitive exchange rate will avoid the two gap problem, or, in other words, will liberate the national economy from the need of foreign finance or of the policy of growth with foreign savings. Instead of promoting investment and savings, the increase in foreign indebtedness usually promotes consumption, causes financial fragility, and, eventually, a balance of payment crisis.

Graph 1 summarizes the structuralist development macroeconomics and new developmentalism. In the vertical axe we have the exchange rate and in the horizontal, time. According to conventional economics, the exchange rate fluctuates nicely around the current equilibrium exchange rate; to Keynesians, it also fluctuates around the same line, but is volatile; according to the ideas shortly resumed here, however, the tendency to the overvaluation of the exchange rate means that it is not controlled by the market but by currency or balance of payment crises. During crises, the national currency experiences a sharp devaluation, but, in the following years, if the government does not intervene to neutralize the tendency - the Dutch disease brings the exchange rate to the current level; from this point downwards, appreciation is caused by the inflow of foreign capitals attracted by high structural and policy defined interest rates, by the policy of growth with foreign savings, by the use of nominal anchors, by the use of inflation targeting as a substitute for a nominal anchor, capital deepening policies, and exchange rate populism.

As this downward movement takes place, wages, artificially increased by the appreciation of the currency, cause increase in consumption; the current account deficit appears and increases steadily; foreign indebtedness increases; and, eventually, foreign creditors, concerned with the high current account deficit and the high foreign debt, suspend the rollover of the foreign debt and cause a sudden stop: the balance of payment crisis that again depreciates the currency.

\footnotetext{
${ }^{7}$ The two gap model asserted that besides the savings constraint, developing countries face a foreign currencies constraint, thus needing loans or investments from rich countries.
} 


\section{Old and new developmentalism}

I will shortly compare new developmentalism with the other two strategies - old national developmentalism and conventional orthodoxy - beginning by the former. I see five main differences between national developmentalism and new developmentalism, all related to the fact that many countries remain developing but have ceased to be poor, are not anymore characterized by infant industries, and are now middle-income countries. This fact has a first and major consequence: while old developmentalism was relatively protectionist, new developmentalism is not; whereas old developmentalism was based on import substitution, new developmentalism is export led. In the 30 golden years after the Second World War, middle-income countries did not represent competition or a threat to rich nations. Yet, since the 1970s, with the NICs (newly industrializing countries) and, since the 1990s, with China and finally India, they have become much more competitive. In this context, manufacturing industry has ceased to be infant and, thus, does not require generalized protection. Between the 1930s and the 1950s, the import-substitution model was effective in establishing the industrial bases of Latin American countries. The tariffs were a way to protect infant industry and also to neutralize the Dutch disease on the import side. After the mid-1960s, however, governments should have begun dropping some of their tax barriers to imports and adopting an export-led model combined with the development of the domestic market. Some countries, principally Brazil and Mexico, did orient their exports to manufacturing, but retained high import taxes. It was only in the late1980s and early 1990s that trade liberalization took place, in the middle of a major economic crisis, and often hurriedly and haphazardly. This was a mistake because in countries like Brazil and Argentina import taxes were not just a response to the infant industry problem, but a way of neutralizing, on the import side, the Dutch disease caused by the highly favorable natural conditions that these countries offer for cattle breeding and agricultural exports.

New developmentalism is not protectionist: it simply emphasizes the need for a competitive exchange rate, i.e., an exchange rate that turns viable other tradable industries utilizing technology in the state of the art besides the one that originates the Dutch disease. It assumes that middle-income countries have already passed through the infant-industry stage but still face the Dutch disease and, for that reason, experience long-term appreciation of their exchange rate that is consistent with equilibrium in the current account balance, but renders economically not viable other tradable industries using 
technology in the state of the art. The larger the gap between the current equilibrium and the industrial equilibrium exchange rate, the more "serious" will be the disease - the higher will be the obstacle to other tradable industries to prosper. In the more serious the disease, the more the country will be impeded of transferring labor from the production of lower to higher per capita valued-added goods or from simple to sophisticated industries a key structural condition for economic growth. ${ }^{8}$ In order to neutralize the Dutch disease, the basic policy is to impose a tax or a retention on exports of the good (or goods) that originate it; such tax will shift upwards the supply curve of theses goods; if the tax is sufficient, exports of that good that were viable at the current equilibrium exchange rate now will be only viable at the industrial equilibrium - the exchange rate level that makes viable all other tradable industries utilizing technology in the state of the art. Tariff protection does this job only partially, limited to the import side. To include the export side and make industries utilizing modern technology able to export it is required a tax on exports of the goods ${ }^{9}$

Chart 1: Old and new developmentalism

\begin{tabular}{|l|l|}
\hline \multicolumn{1}{|c|}{ Old developmentalism } & \multicolumn{1}{c|}{ New developmentalism } \\
\hline $\begin{array}{l}\text { 1. Industrialization is state-led and } \\
\text { based on import substitution. }\end{array}$ & $\begin{array}{l}\text { 1. Export-led industrialization } \\
\text { combined with strong domestic } \\
\text { market. }\end{array}$ \\
\hline $\begin{array}{l}\text { 2. Leading role for the state in } \\
\text { obtaining forced savings and in } \\
\text { making investments. }\end{array}$ & $\begin{array}{l}\text { 2. The state is supposed to create } \\
\text { investment opportunities and reduce } \\
\text { economic inequalities. }\end{array}$ \\
\hline $\begin{array}{l}\text { 3. Industrial policy is central. } \\
\text { 4. Mixed attitude in relation to budget } \\
\text { deficits. }\end{array}$ & $\begin{array}{l}\text { 3. Industrial policy is subsidiary; the } \\
\text { essential is a competitive exchange }\end{array}$ \\
\hline $\begin{array}{l}\text { 5. Rejection of fiscal deficits. If the } \\
\text { country suffers from the Dutch } \\
\text { disease, it should have current } \\
\text { account and fiscal surplus. }\end{array}$ \\
\hline inflation. & $\begin{array}{l}\text { 5. No complacency towards } \\
\text { inflation. }\end{array}$ \\
\hline
\end{tabular}

\footnotetext{
${ }^{8}$ As José Antonio Ocampo and Rob Vos (2008: 34) observe, "productivity growth in developed countries mainly relies on technological innovation. For developing countries, however, growth and development are much less about pushing the technology frontier and much more about changing the structure of production towards activities with higher levels of productivity"

${ }^{9}$ Bresser-Pereira (2008, 2010).
} 
Unlike old developmentalism, which embraced the export pessimism of development economics, new developmentalism lays odds on the ability of developing countries to export medium value-added manufactured goods or high value-added primary products. The experience of the past thirty years has clearly shown that export pessimism was one of the great theoretical mistakes of development economics. In the late 1960s, Latin American countries should have begun shifting decisively from the import-substitution model to the export-led model, such as Korea and Taiwan did. In Latin America, Chile was the first to effect such a change and, as a result, is often pointed to as an example of a successful neoliberal strategy of development. In fact, neoliberalism was fully practiced in Chile only between 1973 and 1981, coming to an end with a major balance-of-payments crisis in $1982 .{ }^{10}$ The export-led model is not neoliberal if it is combined with an expanding domestic market and with the neutralization of the Dutch disease (what Chileans do by taxing cover exports). The fast-growing Asian countries originally adopted an importsubstitution strategy, but soon changed to an export-led model, which has two main advantages over the import-substitution model. First, the industries are not limited to the domestic market. This is important for small countries but equally fundamental to a country with a relatively large domestic market. Second, if a country adopts this strategy, the economic authorities will frame an industrial policy to benefit their national firms, automatically establishing an efficiency criterion to guide them: only efficient firms will benefit from the industrial policy. In the case of the import-substitution model, very inefficient firms may be enjoying the benefits of protection; in the case of the export-led model, the likelihood of this to happen is substantially smaller.

A second difference between old and new developmentalism concerns the role of the state. In the 1950s, under national developmentalism, countries were poor, and the state was supposed to play a leading role in achieving forced savings and in investing not only in monopolistic industries but also in industries characterized by large economies of scale and, so, requiring huge sums of capital. Fifty years later, most of the Latin American nation-states are middle-income countries; they have already completed or are involved in their own capitalist revolutions; they are equipped with a stock of capital that did not exist before, able to finance investment; they are equipped with entrepreneurial, professional and working classes able to industrialize and modernize their countries. The state

\footnotetext{
${ }^{10}$ See Alejandro (1981) and Ffrench-Davis (2003).
} 
continues to play a key role, but a normative, enabling and encouraging role rather than a direct role in production. Both forms of developmentalism cast the state in a leading role in terms of ensuring the proper operation of the market and providing the general conditions for capital accumulation, such as education, health, transportation, communications and power infrastructures. In addition, however, under the developmentalism of the 1950s, the state also played a crucial role in promoting forced savings, thereby contributing to countries' primitive accumulation processes; furthermore, the state made direct investments in infrastructure and heavy industry where the sums required exceeded the private sector's savings.

This has changed since the 1980s. With new developmentalism, the state still can and must promote forced savings and invest in certain strategic industries, but the national private sector has now the resources and managerial ability to provide a sizable portion of the necessary investment. New developmentalism rejects the neoliberal thesis that "the state no longer has resources”, because whether or not the state has resources depends on how its finances are managed. But new developmentalism understands that, in all sectors where reasonable competition exists, the state must be not an investor; instead, it must concentrate on defending and ensuring competition. Even after these investments have been excluded, there are many left to the state to finance with public savings rather than debt.

Third, new developmentalism supports industrial policy but rejects the preeminent role played in national developmentalism. More important than an industrial policy is a competent macroeconomic policy based on fiscal balance, moderate interest rates and a competitive exchange rate - an exchange rate that makes viable or competitive industries using the best technology available in the world. The state may, and is supposed to, support business enterprises, but only strategically, not permanently. And it is supposed to make this support conditional on businesses achieving international competitiveness.

Fourth, new developmentalism rejects misleading notions of growth based chiefly on chronic public deficits - an equivocal idea that became popular in Latin America, but was not shared by the main economists who originally defined it. This was one of the most severe distortions that national developmentalism endured in the 1980s in the hands of its latter-day populist advocates. Keynes, in whose name economic populism was promoted, pointed out the importance of aggregate demand and legitimized resorting to public 
deficits in recessions, but he never advocated chronic public deficits. He always assumed that a fiscally balanced national economy might, for a brief while, give up this balance to re-establish employment levels. The notable economists who formulated the developmentalist strategy, such as Furtado, Prebisch, and Rangel, were Keynesians, and they regarded aggregate demand management as an important tool for promoting development. But they never defended the economic populism of chronic deficits. Those who came in their wake, however, did. When Celso Furtado, faced with the severe crisis of the early 1960s, proposed his Plano Trienal (1963), these second-rate propagandists accused him of having an "orthodox rebound."

New developmentalism defends fiscal equilibrium, not in the name of "orthodoxy" but because it realizes that the state is the nation's instrument for collective action par excellence. If the state is so strategic, its apparatus must be strong, sound and capacious; and for this very reason, its finances must be in balance. More than this, its debt must be small and long in maturity. The worst thing that can happen to a state as an organization (the state also stands for the rule of law) is to be in thrall to creditors, be they domestic or foreign. Foreign creditors are particularly dangerous, because they and their capital may, at any time, leave the country. However, domestic creditors, transformed into rentiers and supported by the financial system, can impose disastrous economic policies on the country. If the country suffers the Dutch disease and is able to neutralize it, it will shift from the current to the industrial equilibrium exchange rate, and will experience current account surpluses. Since the best practice, in this case, is to build a sovereign fund abroad in order to avoid the inflow of capitals and the re-evaluation of the currency; this fund should be financed by a corresponding fiscal surplus.

Fifth and last, new developmentalism is different from national developmentalism because, while the latter was relatively complacent about inflation, new developmentalism is not. Old developmentalism had good reason to be relatively complacent: the structural theory of inflation asserted that, due to the imperfections of domestic markets, developing countries should live with moderate rates of inflation. In middle-income countries, markets are not so imperfect, and experience has shown that inflation may turn into a curse.

In sum, and, again, because middle-income countries are at a different stage, new developmentalism is more favorable to the market as an efficient institution to coordinate the economic system than was old developmentalism, although its perspective is far 
removed from the irrational faith in the market evinced by conventional orthodoxy.

\section{New developmentalism and conventional orthodoxy}

In this paper I am sponsoring new developmentalism, but conventional orthodoxy is still dominant, principally in defining macroeconomic policy in Latin America. Let us now examine the differences between these two competing strategies. Conventional economic orthodoxy is made up of a set of theories, diagnoses and policy proposals that rich nations offer to developing countries. It is based on neoclassical economics but it should not be confused with it, because it is not theoretical but openly ideological and oriented toward institutional reforms and economic policies. While neoclassical economics is based in universities, particularly in the United States, conventional orthodoxy springs mainly from Washington, DC, home of the US Treasury Department and of the two agencies that are supposedly international but that, in fact, are subordinate to the U.S. Treasury: the International Monetary Fund and the World Bank. The former is charged with macroeconomic policy and the latter with development. Second, conventional orthodoxy originated in New York, the headquarters or the point of convergence of major international banks and multinational corporations. Conventional orthodoxy changes over time. Since the 1980s, it has become identified with the "Washington Consensus," which cannot be understood simply as the list of ten reforms or adjustments that John Williamson (1990) wrote in the paper that gave birth to the expression. His list included reforms and adjustments that were and still are necessary. The problem is not in the reforms, but in the radical, laissez faire way that they were understood, and in the inclusion of a reform that Williamson deliberately did not included in his list because he was aware of the risks involved: financial liberalization.

In as much as conventional orthodoxy is the practical expression of neoliberal ideology, it is the ideology of the market versus the state. While new developmentalism requires a strong state and a strong market, and believes there is no contradiction between them, conventional orthodoxy wishes to strengthen the market by weakening the state, as if the two institutions were parties in a zero-sum game. In the twentieth century the state has grown in terms of tax burden and of the level of market regulation as a result of the increased dimensions and complexity of modern societies, or, in other words, as an outcome of the fact that a strong and relatively large state is a requirement for a strong and 
competitive market. Nevertheless, conventional orthodoxy sees this growth as just the consequence of populist politicians and of a state friendly bureaucracy. Certainly, the state has also grown as a result of clientelism and of pressures of the bureaucracy to have more positions to occupy in the state organization, but conventional orthodoxy does not distinguish legitimate state growth from the illegitimate variety.

The central difference between conventional orthodoxy and new developmentalism lies in the fact that conventional orthodoxy believes that the market is an institution that coordinates production optimally if it is free of interference, whereas new developmentalism views the market as an efficient institution to coordinate economic systems, but knows its limitations and the need for regulation. Factor allocation is the task that it performs best, but even here it faces problems. In stimulating investment and innovation, it is insufficient, because it fails to neutralize the two structural tendencies existing in developing countries that we already shortly discussed: the tendency of the exchange rate to overvaluation and the tendency of wages to increase less than productivity. Besides, markets are a clearly unsatisfactory mechanism in distributing income, favoring the stronger and more capable participants. While conventional orthodoxy acknowledges market failures but asserts that state failures are worse, new developmentalism rejects such pessimism about the possibilities of collective action and demands a capable state - not as a trade-off for a weak market but combined with a strong market. If human beings are able to build institutions to regulate human actions, including the market itself, there is no reason why they should not be able to strengthen the state organization or apparatus (making its administration more legitimate, its finances more solid, and its management more efficient) or to strengthen the constitutional or legal system (increasingly adjusting its institutions to social needs). Politics and democracy exist precisely for that purpose; and the more advanced democracies have been making major advances in this area in the last century.

Insofar as one of the foundations of new developmentalism is classical political economy, which was essentially a theory of the "wealth of nations" (Smith) and of capital accumulation (Marx), social structures and institutions are fundamental to its reasoning. Besides, as it adopts a historical approach to economic development, the teachings of Keynes and Kalecki (whose method was essentially historical-deductive instead of hypothetical-deductive), of the German Historical School and of the American 
Institutionalist School are an essential part of this vision. ${ }^{11}$ Institutions are fundamental, and to reform them is a permanent requirement insofar as, in the complex and dynamic societies, economic activities must be constantly re-regulated. In contrast, conventional orthodoxy, based on neoclassical economics, only recently acknowledged the role of institutions, in the context of "new institutionalism." Differently from historical institutionalism that sees pre-capitalist institutions as obstacles to economic growth, and actively seeks to develop a set or cluster of institutions (a national growth strategy) to create investment opportunities to business entrepreneurs, new institutionalism offers a simplistic answer to the problem: it is sufficient that institutions guarantee property rights and contracts, or, more broadly, the good working of markets, which will automatically promote growth.

In comparing new developmentalism and conventional orthodoxy, it is difficult to distinguish macroeconomic policies from growth strategies because, in the context of a structuralist development macroeconomics, these two levels are closely intertwined. Growth is impossible without stability. The macroeconomic prices - the profit rate, the interest rate, the wage rate, the inflation rate and the exchange rate - are not just determinants of macroeconomic stability, policies in relation to them are crucial for economic growth.

Following approximately the paragraphs in Charts 2 and 3 that, respectively, resume mostly growth and mostly macro policies, let us compare the two strategies. First, conventional orthodoxy ignores the existence of nations, whereas new developmentalism emphasizes their existence, and underlies that in globalization they became more interdependent and more strategic because economic competition is not restricted to business enterprises, but also to nations. Second, whereas conventional orthodoxy sees property rights and contracts as the key institutions to growth, new developmentalism asserts that a national development strategy plays this role insofar as it is a cluster of laws, policies, understandings and values that create investment opportunities to business entrepreneurs.

\section{Chart 2: Conventional orthodoxy and new developmentalism (growth)}

\footnotetext{
${ }^{11}$ The German Historical School is the school of Gustav Schmoller, Otto Rank, Max Weber, and, in a different line, of Friedrich List; the American Institutionalist School is the school of Thorstein Veblen, Wesley Mitchell, and John R. Commons.
} 


\begin{tabular}{|l|l|}
\hline \multicolumn{1}{|c|}{ Conventional orthodoxy } & \multicolumn{1}{|c|}{ New developmentalism } \\
\hline $\begin{array}{l}\text { 1. No economic role for the nation. } \\
\begin{array}{l}\text { 2. The fundamental institutions to promote } \\
\text { growth are property rights and contracts. }\end{array}\end{array}$ & $\begin{array}{l}\text { 1. The nation is the agent defining the national } \\
\text { 2. The key institution to promote growth is a } \\
\text { national development strategy. }\end{array}$ \\
\hline $\begin{array}{l}\text { 3. Reforms reducing the size of state and } \\
\text { deregulating markets. }\end{array}$ & $\begin{array}{l}\text { 3. Reforms strengthening the state and markets } \\
\text { - the later by being regulated, not } \\
\text { deregulated. }\end{array}$ \\
\hline $\begin{array}{l}\text { 4. Minimal role of the state in investing and in } \\
\text { industrial policy. }\end{array}$ & $\begin{array}{l}\text { 4. Moderate role in investing and in industrial } \\
\text { policy; large role in redistribution. }\end{array}$ \\
\hline $\begin{array}{l}\text { 5. No structural tendencies. } \\
\text { 6. Growth financed with foreign savings. } \\
\text { exchange rate and to wages to increase less } \\
\text { than productivity. }\end{array}$ \\
\hline
\end{tabular}

Third, conventional orthodoxy supports institutional reforms that reduce the size of the state and strengthen the market and ascribes a minimal role to the state in investment and industrial policy, whereas new developmentalism supports reforms strengthening markets and enabling the state to perform its regulatory and investment stimulating role. For new developmentalism, the state is the main instrument of collective action of the nation - of a national society with a sense of common destiny and of reasonable solidarity when competing internationally. Fourth, conventional orthodoxy sees no role for the state in investment and in industrial policy, whereas new developmentalism aims at a capable and efficient state able to make public investments that are not attractive to the private sector or that are monopolists, or that involve huge rents as is the case of the oil industry, and believes that a strategic industrial policy remains necessary. New developmentalism gives priority to export industries and to high per capita value-added industries, that is, industries with a high technological or knowledge content.

Fifth, conventional orthodoxy sees no structural tendencies to tackle, whereas new developmentalism identifies the two major tendencies already discussed: the tendency of wages to increase below the productivity rate, and of the exchange rate to get overvalued and be "controlled" by balance of payment crises instead of by the market. Sixth, conventional orthodoxy believes and strongly asserts that growth of middle income countries should be financed with foreign savings, because they would not count with domestic savings to finance their growth, whereas new developmentalism rejects this assertion. Foreign savings do not need to be rejected, but they involve a high rate of 
substitution for domestic savings. This rate of substitution tends to be high even when foreign direct investments finance the current account deficit. Thus, the country should aim a current account balance and grow with domestic savings. Foreign investments oriented to the domestic market are welcome provided that they have as counterpart the opening of the rich countries to investments of the middle-income countries. New developmentalism believes that it is not only necessary but possible to increase domestic saving, but, for that, the first condition is to have a competitive instead of a chronically overvalued currency that increases artificially wages and consumption.

Seventh, now entering the realm of macroeconomic policy, the central bank has a single mandate: to control inflation; other objectives are to be pursued by the government. In contrast, for conventional orthodoxy the central bank should have a triple mandate: in association with the finance ministry, the central bank should control inflation, keep the exchange rate competitive (compatible with the current account balance and the gradual transfer of manpower to more knowledge-intensive or high per capita value-added industries) and achieve reasonably full employment. Thus, there is not full independence to the central bank, insofar as this role should be performed together with the government.

Contrary to what neoclassical macroeconomics asserts, the central bank does not have at its disposal a single instrument but several instruments besides the interest rate: it may buy reserves and establish capital inflow controls to avoid the tendency of the exchange rate to relative appreciation, a common tendency among middle-income countries. The interest rate is an instrument to control inflation, but its average level may be considerably lower than conventional orthodoxy assumes for developing countries.

\section{Chart 3: Conventional orthodoxy and new developmentalism (macro)}

\begin{tabular}{|l|l|}
\hline \multicolumn{1}{|c|}{ Conventional orthodoxy } & \multicolumn{1}{|c|}{ New developmentalism } \\
\hline $\begin{array}{l}\text { 7. The central bank has a single mandate target: } \\
\text { inflation. Other objectives are to be pursued by } \\
\text { the government. }\end{array}$ & $\begin{array}{l}\text { 7. The central bank and the government have } \\
\text { three mandate targets: inflation, exchange rate, } \\
\text { and employment. }\end{array}$ \\
\hline $\begin{array}{l}\text { 8. The primary surplus is the central fiscal } \\
\text { standard. }\end{array}$ & $\begin{array}{l}\text { 8. The budget deficit and public savings are the } \\
\text { central fiscal standards. }\end{array}$ \\
\hline $\begin{array}{l}\text { 9. Fully floating exchange rate; no exchange rate } \\
\text { objective, nor related policy. }\end{array}$ & $\begin{array}{l}\text { 9. Floating but administered exchange rate; the } \\
\text { competitive exchange rate corresponds to } \\
\text { "industrial equilibrium" exchange rate. }\end{array}$ \\
\hline $\begin{array}{l}\text { 10. The central bank uses a single instrument: the } \\
\text { short-term interest rate; the government keeps } \\
\text { public deficit under control. }\end{array}$ & $\begin{array}{l}\text { 10. The central bank may also buy reserves, and } \\
\text { the government besides controlling the budget } \\
\text { may impose controls on capital inflows. }\end{array}$ \\
\hline
\end{tabular}


Eight, for conventional orthodoxy the primary surplus is the central fiscal objective, whereas new developmentalism is more demanding in this matter: it wants that public savings finance most of public investments, and consider the convenience of budget surplus if, in consequence of the neutralization of the Dutch disease, current account surplus materializes. We already mentioned that the country should neutralize the Dutch disease with the help of a tax or retention on sales or exports that shifts the supply curve of the Dutch disease goods to the competitive equilibrium - the industrial one. In consequence, it should portray a fiscal surplus insofar as the revenues from the tax or "retention" on the goods originating the disease should not be expended, but used to build a sovereign fund.

According to structuralist development macroeconomics, the exchange rate is not only a macroeconomic price. It is also a major instrument of growth, as recent researches have been demonstrating. ${ }^{12}$ Before the 1990s, conventional orthodoxy was concerned with foreign exchange rates and, during balance-of-payments crises, always demanded foreignexchange depreciations in addition to fiscal adjustments. Since the 1990s, however, this policy was abandoned. Instead, the IMF has practically forgotten current account deficits (they were foreign savings) and limited its recommendations to exchange rate depreciation. The twin-deficit hypothesis exempted it from worrying about current account deficits: all it had to do was to concern itself with the primary surplus. For a while, it chose to support foreign exchange-rate anchors and dollarization; after the failure of that strategy in Mexico, Brazil and, above all, Argentina, the IMF turned to fully floating exchange rates combined with inflation targeting - another and more indirect way of imposing a nominal anchor to the economy insofar as the appreciation of the currency caused by high interest rates represented the main outcome of the inflation targeting policy.

\footnotetext{
${ }^{12}$ There is a growing literature relating the exchange rate with investments, savings, and growth (Razin and Collins 1997, Bresser-Pereira and Nakano 2003, Gala 2006, Bresser-Pereira and Gala 2007, Eichengreen 2008, Rodrik 2008 and Williamson 2008, Bresser-Pereira 2010).
} 
Thus, ninth, conventional orthodoxy supports a fully floating exchange rate, defines no exchange rate objectives, and rejects the possibility of an exchange rate policy, whereas new developmentalism wants a floating but managed exchange rate, and aims at a competitive exchange rate that corresponds to the industrial equilibrium, i.e., to the rate that makes economically viable and tradable industries utilizing the best technology. Conventional orthodoxy insists that it is "impossible" to manage the long-term exchange rate, but historical evidence shows the contrary; this may be true for the United States, where the dollar is the international reserve currency, but it is not true for other countries. Tenth, for conventional orthodoxy the central bank uses a single instrument: the short-term interest rate while the government keeps public deficit under control. In contrast, for new developmentalism the central bank may also buy reserves, and the government besides controlling the budget may impose control on capital inflows. The argument that capital controls are not viable is not empirically correct; the inference that, given Mundell's triangle of impossibility, countries are supposed to renounce capital controls to have autonomy in monetary policy and guarantee capital mobility starts from the assumption that capital mobility is preferable to control of the exchange rate - what is at least debatable.

Finally, since developing countries are dualistic countries that face the problem of an unlimited supply of labor, there is the tendency of wages to increase more slowly than productivity. Thus, there is a tendency to the concentration of income that must be checked by economic policy - particularly by a minimum wage policy and a large program of social expenditures in education, health care, social assistance and social security - not only for distributive reasons, but also because inequality is a source of political instability that is eventually a major obstacle to growth (Przeworski and Curvale 2006).

\section{Conclusion}

Summing up, new developmentalism draws on the experience of fast growing Asian countries and on a structuralist development macroeconomics. This approach is based on two structural tendencies that grow on the demand side: the tendency to the overvaluation of the exchange rate and the tendency of wages to grow below the increase of productivity. The first tendency calls principally for the neutralization of the Dutch disease 
and growth with domestic savings, and the second tendency calls for incomes policy, particularly for minimum wage and social expenditures policy, As to short-term macroeconomic policies, they must be oriented to responsible fiscal practices, a moderate average interest rate and a competitive exchange rate; this is the policy tripod of new developmentalism, whereas conventional orthodoxy usually supports high interest rates and overvalued exchange rate. Both strategies support fiscal discipline, but only new developmentalism asks for a balanced current account.

Can new developmentalism become hegemonic in Latin America, as developmentalism was in the past? I believe so, since Keynesian-structuralist economists show to the business and political elites of the region that they offer a practical and responsible cluster of policies - policies that will increase financial stability and that will make economic growth substantially higher. Since the early 2000s it is becoming clear that the time of Washington Consensus is over; the present global financial crisis has put a definitive end to it. New perspectives are opening up for Latin America. In the framework of new developmentalism, each individual country now has the possibility of adopting effectively national development strategies - strategies that widen the role of the state in regulating markets, that create profit opportunities stimulating private investment and innovation, and that increase the country's international competitiveness while protecting labor, the poor and the environment.

\section{References}

Alejandro, Carlos Diaz (1981) “Southern Cone stabilization plans,” in W. Cline and S. Weintraub, eds. Economic Stabilization in Developing Countries. Washington DC: Brookings Institution.

Bacha, Edmar L. (1973 [1976]) “The unequalizing spiral: a first growth model for Belindia”, Quarterly Journal of Economics 90 (2) May: 197-218. Written and circulated in 1973.

Bielschowsky, Roberto (2008) “Desenvolvimento econômico, inclusão social e a dinâmica de consumo de massa”, Brasília, apresentação Power Point na ESAF - Escola de Administração Fazendária do Ministério da Fazenda, setembro de 2008.

Bresser-Pereira, Luiz Carlos (1970) "Dividir ou multiplicar? A distribuição da renda e a recuperação da economia brasileira” [Divide or multiply? Income distribution and the 
recovery of the Brazilian economy], Visão, November 21, 1970. Included in Development and Crisis in Brazil, Bolder: Westview Press,1984: 143-148. Available at www.bresserpereira.org.br.

Bresser-Pereira, Luiz Carlos (1974) "El nuevo modelo brasileño de desarrollo” [The new Brazil development model], Desarrollo Económico, Buenos Aires, 55(14) October 1974: 569-88.

Bresser-Pereira, Luiz Carlos (1977) Estado e Subdesenvolvimento Industrializado [State and Industrialized Underdevelopment]. São Paulo: Editora Brasiliense.

Bresser-Pereira, Luiz Carlos (2006) “De la CEPAL y del ISEB a la teoría de la dependencia” [From ECLAC and ISEB to dependency theory], Desarrollo Económico, 183, octubre-diciembre: 419-440.

Bresser-Pereira, Luiz Carlos (2008) “Dutch disease and its neutralization: a Ricardian approach”, Brazilian Journal of Political Economy 28 (1): 47-71.

Bresser-Pereira, Luiz Carlos (2009) "From the national-bourgeois to the associated dependency interpretation of Latin-America”, forthcoming in the Journal of Interamerican Studies.

Bresser-Pereira, Luiz Carlos (2010) Globalization and Competition, Cambridge: Cambridge University Press.

Bresser-Pereira, Luiz Carlos and Yoshiaki Nakano (1984 [1987]) The Theory of Inertial Inflation, Boulder: Lynne Rienner Publishers. Original Portuguese edition, 1984.

Bresser-Pereira, Luiz Carlos e Paulo Gala (2007) "Why foreign savings fail to cause growth”, Brazilian Journal of Political Economy 27 (1): 3-19. In Portuguese, in the printed edition; in English, in the journal's website: www.rep.org.br.

Bresser-Pereira, Luiz Carlos e Yoshiaki Nakano (2003) "Economic growth with foreign savings?" Brazilian Journal of Political Economy 22 (2) April 2003: 3-27. In Portuguese, in the printed edition; in English, in the journal's website: www.rep.org.br. Canitrot, Adolfo (1975) “La experiencia populista de distribución de renta” [The populist experience of income distribution], Desarrollo Económico 15(59): 331-51. 
Cardenas, Henrique, José Antonio Ocampo and Rosemary Thorp, eds. (2001) An Economic History of Twentieth-century Latin America: Volume 1: The Export Age, London: Palgrave-Macmillan.

Cardoso, Fernando Henrique and Enzo Faletto (1969[1979]) Dependency and Development in Latin America. Berkeley: University of California Press. Originally published in Spanish, 1969.

Chang, Ha-Joon (2002) Kicking Away the Ladder, London: Anthem Press.

Dutt, Amitava Krishna and Jaime Ross (2003) “Development economics and political economy”, in Amitava Krishna and Jaime Ros, eds. (2003): 3-30.

Dutt, Amitava Krishna and Jaime Ross eds. (2003) Development Economics and Structuralist Macroeconomics, Cheltenham: Edward Elgar:

Eichengreen, Barry (2008) “The real exchange rate and economic growth”, UC Berkeley, mimeo.

Ffrench-Davis, Ricardo (2003) Entre el Neoliberalismo y el Crecimiento con Equidad [Between Neoliberalism and Growth with Equity], third edition. Santiago de Chile: J. C. Sáes Editor.

Ffrench-Davis, Ricardo (2003) Entre el Neoliberalismo y el Crescimiento com Equidad Terceira Edição. Santiago do Chile: J. C. Sáes Editor.

Frank, Andre Gunder (1966) “The development of underdevelopment”, Monthly Review 18(4): 17-31.

Frenkel, Roberto (2003) “Globalización y crisis financieras en América Latina” [Globalization and financial crises in Latin America”, Revista de Economia Política, 23(3): 94-111.

Frenkel, Roberto (2008) “Tipo de cambio real competitivo, inflación y política monetaria”, Revista de la CEPAL 96: 189-200.

Furtado, Celso (1959 [1963]) The Economic Growth of Brazil. Los Angeles: University of California Press. Original Brazilian publication, 1959.

Furtado, Celso (1963) Plano Trienal de Desenvolvimento Econômico e Social (1963-1965) [The Three Years Plan of Economic and Social Development (1963-1965)]. Rio de Janeiro: Síntese. 
Furtado, Celso (1966 [1970]) Obstacles to development in Latin America. New York: Anchor Books-Doubleday. Original Brazilian publication, 1966.

Gala, Paulo (2006) Política Cambial e Macroeconomia do Desenvolvimento [Exchange Rate Policy and Development Macroeconomics], São Paulo: São Paulo School of Economics of Getulio Vargas Foundation, PhD dissertation, May 2006.

Gellner, Ernest (1983) Nations and Nationalism. Ithaca: Cornell University Press.

Gellner, Ernest (1993 [2000]) “The coming of nationalism and its interpretation: the myths of nation and class”, in Gopal Balakrishnan \& B. Anderson, eds.. Mapping the Nation, London: Verso: 98-145.

Lewis, Arthur W. (1954) “Economic development with unlimited supply of labor”. The Manchester School 22: 139-91.

Mankiw, N. Gregory (2006) “The macroeconomist as scientist and engineer”, Journal of Economic Perspectives 20 (4): 29-46.

Ocampo, José Antonio and María Angela Parra (2007) "Explaining the dual divergence: the role of special shocks and specialization patterns”, in José Antonio Ocampo, K. S. Jomo and Rob Vos, eds. (2007): 98-127.

Ocampo, José Antonio and Rob Vos (2008) Uneven Economic Development, London: Zed Books, in association with United Nations.

Ocampo, José Antonio, K. S. Jomo and Rob Vos, eds. (2007) Growth Divergences, London: Zed Books, in association with United Nations.

Pazos, Felipe (1972) Chronic Inflation in Latin America. New York: Praeger Publishers.

Przeworski, Adam and Carolina Curvale (2006) “Explica la política la brecha económica entre Estados Unidos y América Latina?” [Does politics explain the economic gap between the United States and Latin America?], in Francis Fukuyama, ed. La Brecha entre América Latina y Estados Unidos, Buenos Aires: Fondo de Cultura Económica: 129-66. Available in English in www.bressserpereira.org.br.

Razin, Ofair and Suzan M. Collins (1997) "Real exchange rate misalignments and growth", National Bureau of Economic Research, Working Paper 6147, September. 
Rodrik, Dani (2007) “The real exchange rate and economic growth: theory and evidence”, John F. Kennedy School of Government, Harvard University, Cambridge, MA, July 2007. 36 pages.

Ros, Jaime (2003) "Inflation, stabilization and growth: multiple equilibria in a structuralist model”, in Amitava K. Dutt and Jaime Ross, eds. (2003): 227-246.

Sachs, Jeffrey D. (1990) “Social conflict and populist policies in Latin America”, in R. Brunetta and C. Dell-Arringa, eds. Labor Relations and Economic Performance. London: Macmillan.

Tavares, Maria da Conceição and José Serra (1971[1972]) “Além da estagnação” [Beyond stagnation], in Maria da Conceição Tavares (1972) Da Substituição de Importações ao Capitalismo Financeiro [From the Imports Substitution to the Finance Capitalism], Rio de Janeiro: Editora Zahar. Originally published in Spanish in 1971.

Taylor, Lance (1983) Structuralist Macroeconomics, New York: Basic Books.

Taylor, Lance (1991) Income Distribution, Inflation, and Growth, Cambridge: The MIT Press.

Williamson, John (1990) “The progress of policy reform in Latin America”, in John Williamson, ed. Latin American Adjustment: How Much Has Happened? Washington, DC: Institute for International Economics: 353-420.

Williamson, John (2008) “Exchange rate economics”, Working Paper Series, Peterson Institute for international economics, Washington. 